\title{
What Are the Fiscal Costs of a (Great) Recession?
}

\author{
Miguel Faria-e-Castro, Economist
}

T he Financial Crisis of 2008 and related Great Recession raised the U.S. federal debt and fiscal deficit to record peacetime levels. Figure 1 shows these two variables: Federal debt increased from 62 percent of gross domestic product (GDP) in 2007 to over 100 percent in 2013. Recessions, especially large ones, can be costly affairs for taxpayers. Why is that?

One can decompose changes in the federal deficit into automatic stabilizers and discretionary policies. Automatic stabilizers are government policies that fluctuate automatically with the business cycle and may help stabilize the economy. For instance, during recessions, higher unemployment leads the government to spend more money on unemployment benefits, while lower incomes reduce income tax revenues. Thus automatic stabilizers generate predictably larger deficits during recessions. These policies comprise the bulk of the federal budget-three-quarters of total federal spending is on entitlement programs, many of which fluctuate substantially with business conditions.

\section{Programs supporting the financial sector comprised most of the fiscal outflow during the Great Recession.}

Congress also annually sets discretionary spending to fund departments, such as for defense and education; agencies, such as NASA and the Environmental Protection Agency (EPA); and a variety of other programs. Discretionary spending accounts for one-quarter of total spending before interest payments.

Many economists argue that the government should increase discretionary spending in recessions to stimulate private consumption and investment, an idea dating back to John Maynard Keynes's analysis of the Great Depression. The Congressional Budget Office has estimated that automatic stabilizers accounted for less than one-third of the increase in the fiscal deficit during 2009-13 (see Figure 1), implying that discretionary spending accounted for the bulk of that increase.

As the U.S. economy entered its worst downturn since the Great Depression, Congress enacted legislation to
Figure 1

The Federal Debt and Deficit Through the Financial Crisis and Great Recession

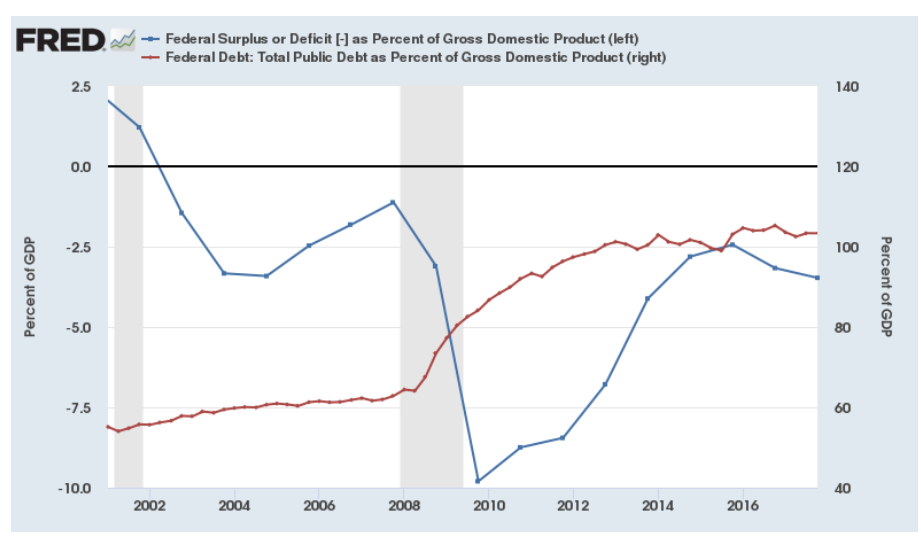

NOTE: Gray bars indicate recessions as determined by the National Bureau of Economic Research.

SOURCE: FRED ${ }^{\circledR}$, Federal Reserve Bank of St. Louis.

increase discretionary spending to stimulate the economy. New programs ranged from financial assistance for large banks and car manufacturers to tax rebates for low-income households and also included funding for public projects, such as highway construction. At its peak, in early 2009, total discretionary spending was about $\$ 1.2$ trillion in annual terms, or 7 percent of GDP.

This spending can be decomposed into four categories: government consumption and investment (i.e., building highways), transfers to households (i.e., tax rebates), support to nonfinancial corporations (i.e., corporate tax credits), and support to the financial sector (i.e., bank bailouts).

Figure 2 illustrates that government consumption and investment were a relatively small fraction of total spending but transfers to households were a relatively large fraction. While these transfers came in many different forms, most of the programs were targeted at lower-income households. Low-income households tend to have a higher propensity to spend income, thus making these transfer programs more likely to stimulate immediate private consumption. Programs supporting the corporate sector also sought to sustain private consumption by preventing businesses from failing and laying off workers. 
Figure 2

\section{Discretionary Spending in the Great Recession}

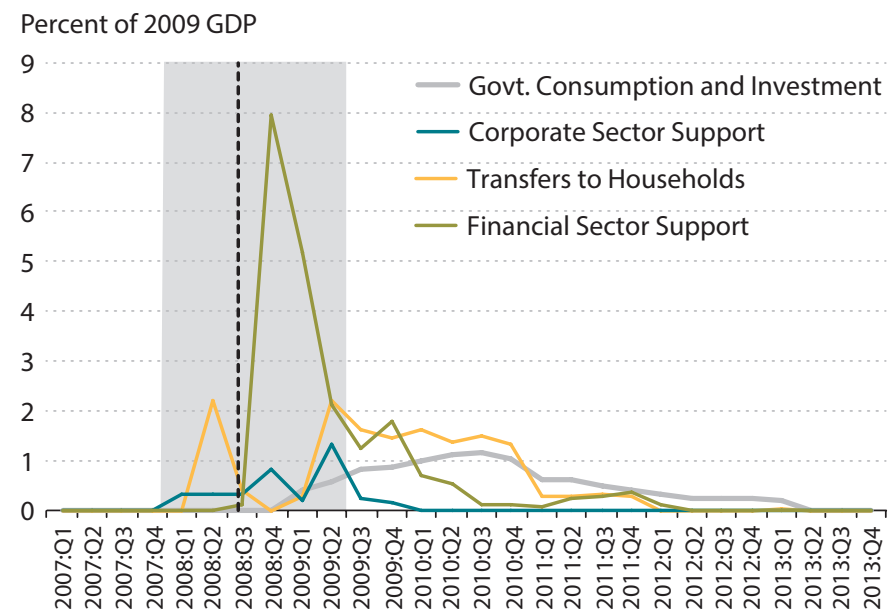

NOTE: The vertical line indicates 2008:Q3, which includes September 2008-the month Lehman Brothers failed and considered the peak of the Financial Crisis. See Faria-e-Castro (2018) for details on the data. Gray bar indicates recession as determined by the National Bureau of Economic Research.

SOURCE: U.S. Treasury; FDIC; Board of Governors of the Federal Reserve System; FRED ${ }^{\circledR}$, Federal Reserve Bank of St. Louis; BEA; and author's calculations.

Programs supporting the financial sector were responsible for most of the fiscal outflow. Policymakers feared that a collapse of the financial sector could seriously restrict firms' and households' access to credit. It should be noted that most of these outflows were not spending in a traditional sense, but rather investments. That is, the Treasury purchased assets such as stock and debt securities to provide temporary support to financial institutions. For that reason, the government was able to recover most of these funds-and even eventually profit—as financial institutions repaid the loans and repurchased the securities.
These simple calculations do not account, however, for the risk the government was taking when purchasing these assets. Had these institutions failed, they would have been unable to repay the government. Taxpayers would then have been on the hook for the large amounts committed to these programs. ${ }^{1}$

While total discretionary spending was large, the implicit risk in the financial sector assistance programs meant that total spending could have been much larger if the crisis had been worse. Since the programs arguably eased financial stress, it is also possible that these commitments to the financial sector prevented the Financial Crisis and recession from becoming much worse. Whether the large increases in discretionary spending actually stabilized macroeconomic and financial conditions remains a topic of ongoing research.

\section{Note}

1 Also not included in these figures are the large credit guarantee programs offered by the U.S. Treasury as well as by government corporations such as the FDIC. Large sums were committed to these credit guarantee programs to which the same logic applies.

\section{References}

Congressional Budget Office. "The Effects of Automatic Stabilizers on the Federal Budget." April 21, 2011.

Faria-e-Castro, Miguel. "Fiscal Multipliers and Financial Crises." Unpublished manuscript, 2018; http://fariaecastro.net/files/fariaecastro_2018.pdf. 